\title{
Detection of a mycoplasma-like organism in peanut plants with witches' broom using indirect enzyme-linked immunosorbent assay (ELISA)
}

\author{
H. A. HOBBS, D. V. R. REDDY and A, S, REDDY \\ legumes Program. International Crops Research Institute for the Semi-Arid Tropics (ICRISAT). \\ Patancheru, PO 50)2 324, Andhra Pradesh. India
}

The mycoplasma-like organism (MLO) associated with peanut (groundnut) witches' broom (PWB) from India was partially purified and an antiserum produced against it. Using a protein $A$ indirect enzyme-linked immunosorbent assay (ELISA) procedure. PWB MLO was detected in crude extracts of leaves, stems and pegs of infected peanut plants, although stems were a better source than leaves and pegs. Extracts of infected tissues of three diseases of assumed MLO etiology in India, little leaf of brinjal (eggplant), l'inca rosea witches' broom, and Datura sp. witches' broom. failed to react with the PWB MLO antiserum.

\section{INTRODUCTION}

Peanut (Arachis hypogaea L.) witches' broom (PWB) occurs in several countries of eastern Asia including China, Taiwan, Indonesia, India and Thailand (Reddy, 1984). Mycoplasma-like organisms (MLOs) have been shown to be associated with PWB (Reddy, 1984). The enzyme-linked immunosorbent assay (ELISA) has been used for detection of MLO agents of several diseases (Clark et ul., 1983: Sinha \& Benhamou 1983; Sinha \& Chiykowski, 1984; Lin \& Chen, 1986). This paper describes the production of an antiserum to the PWB MLO occurring in India. and its use in the detection of PWB MLO in crude extracts using an indirect ELISA procedure.

\section{MATERIALS AND METHODS}

\section{MLO culture and partial purification}

Peanut plants naturally infected with the PWB MLO in the field in Guntur. Andhra Pradesh, were potted and maintained in a screen house by cleft grafting of diseased scions to healthy peanut plants (cv. TMV 2).

Stems and leaflets of plants showing axillary shoot proliferation and small chlorotic leaflets

Submitted as Journal Article No. 613 by the International Crops Research Institute for the Semi-Arid Tropics (ICRISAT). were used in the partial purification. The procedure used was that of Clark et al. (1983) for partial purification of clover phyllody MLO, with several modifications. Diced infected tissue $(20 \mathrm{~g})$ was ground using a chilled mortar and pestle with cold $0.3 \mathrm{M}$ glycine-sodium hydroxide buffer, $\mathrm{pH}$ 8.0 , containing $0.02 \mathrm{M}$ magnesium chloride and $0.02 \mathrm{M}$ sodium sulphite (GMS) at a ratio of $1 \mathrm{~g}$ tissue $108 \mathrm{~m}$ l buffer. The extract was filtcred through cheesecloth and centrifuged at $2000 \mathrm{~g}$ for $15 \mathrm{~min}$. This was followed by high-speed centrifugation at $39000 \mathrm{~g}$ for $\mathrm{I} \mathrm{h}$ and resuspension of the pellets in GMS buffer. Resuspended pellets were then incubated for $45-60$ min at $5 \mathrm{C}$ with 4-5 $\mathrm{ml}$ of undiluted antiserum prepared for healthy peanut leaf extracts. After low-speed centrifugation followed by two additional alternate cycles of high and low speed centrifugation as described above. the final preparation was resuspended in $0.6-1.0 \mathrm{ml}$ of $0.01 \mathrm{~m}$ phosphate buffer, $\mathrm{pH} 7.5$.

\section{Antiserum production and cross absorption}

Partially purified MLO preparation from $20 \mathrm{~g}$ infected tissue was used for a single injection. A New Zealand White inbred rabbit was injected intramuscularly in the hind legs at two to three sites, with an emulsion of equal volumes of partially purified MLO preparation and Freund's incomplete adjuvant. Four injections were given at intervals of 7-10 days, followed by a booster 
injection 18 days after the fourth injection. The rabbit was bled three times at intervals of $7 \cdots 10$ days. starting I week after the booster injection. For cross absorption, antiserum was incubated at $5 \mathrm{C}$ overnight or at $35 \mathrm{C}$ for $3 \mathrm{~h}$ with an equal volume of a preparation from healthy peanut tissue processed in the same way as the PWB MLO preparation. Precipitate was removed by centrifugation at $2000 \mathrm{~g}$ for $15 \mathrm{~min}$.

\section{Protein A indirect ELISA}

Only young infected leaflets with stem tissues. derived from several infected plants, werc employed in all ELISA tests. Infected plants produced very few pegs and they were usually collected from plants 8.10 weeks after graft inoculation. An ELISA procedure for detection of the MLO in crude PWB-infected peanut tissue extracts was standardized. The following procedure, based on a method described by Edwards \& Cooper (1985) was found to be suitable (standard washing steps have been omilted). Coating of EL.ISA plates (Dynatech, Zug. Switzerland) with protein A (Sigma Chemical Co., St Louis, Mo, USA) at I $\mathrm{ng} / \mathrm{ml}$ in $0.05 \mathrm{M}$ sodium carbonate coating buffer, $\mathrm{pH} 9 \cdot 6$, and incubation for $1 \mathrm{~h}$ at $35 \mathrm{C}$ was followed by addition of crossabsorbed antiserum at a dilution of $1: 250$ in PBS. Tween-PVP ovalbumin (Clark \& Adams, 1977). Following incubation of antiscrum for $1 \mathrm{~h}$ at $35 \mathrm{C}$, samples ground in PBS-Tween-PVP containing $0.01 \mathrm{M}$ sodium diethyldithiocarbamate (NaDIECA) were added and incubated for $2 \mathrm{~h}$ at $35 \mathrm{C}$. This was followed by addition of crossabsorbed antiserum at a dilution of 1:250 and incubation for $1 \mathrm{~h}$ at $35 \mathrm{C}$. This antiserum was diluted in healthy peanut extract, to $1: 10$ dilution, with PBS Tween PVP-ovalbumin, filtered through cheesecloth and pre-incubated for 45 min at $35^{\circ} \mathrm{C}$ before addition to the ELISA plate. Anti-rabbit $\mathrm{Fc}$ antibody produced in goats (Cappel Laboratories Inc. West Chester, USA) conjugated to alkaline phosphatase (Sigma) was added next at $2 \mu \mathrm{g} / \mathrm{ml}$ and incubated for $2 \mathrm{~h}$ at $35 \mathrm{C}$. Substrate ( $P$-nitrophenyl phosphate) was added at $0.25 \mathrm{mg} / \mathrm{ml}$, incubated for $1 \mathrm{~h}$ at room temperature, and the reaction was stopped with $3 \mathrm{M}$ $\mathrm{NaOH}$. Absorbances were read at $410 \mathrm{~nm}$ with a Dynatech Micro ELISA Minireader MR 590. pegs from infected plants at each dilution tested. Equivalent values obtained with healthy tissue extracts were no higher than the buffer controls. except for values obtained at the highest concentration (1:I0 w/v) (Table 1).

An experiment was carried out to determine whether samples from several plants could be added together for extraction and placement in a single well of an ELISA plate. Graft-infected peanut plants showing axillary shoot proliferation and chlorotic leaflets were chosen. Stem segments from the apical portion of six infected plants were combined and then mixed with different proportions of healthy stem segments (Table 2). Absorbance values for healthy stem segments (healthy control) were similar to those of buffer. All combinations of infected and healthy tissuc gave positive reactions. In all the experiments absorbance values were similar for extracts diluted up to $1: 400$ in the antigen buffer. However, when extraets were diluted to $1: 1000$ there was substantial reduction in ELISA values. Nevertheless absorbance values for extracts prepared from one part of infected tissue mixed with various parts of healthy tissues depended on the proportion of healthy tissuc. Thus it is apparent that higher proportions of healthy plant components may have interfered with the reaction of PWB antigens with specific $\gamma$-globulins.

Infected samples in the above two experiments werc bulked samples from several shoots. Leaves

Table 1. Enzyme-linked immunosorbent assay (ELISA) detection of peanul witches' broom mycoplasma-Jike organism in leaves, stems and pegs of infected peanut plants

\begin{tabular}{llllll}
\hline & \multicolumn{5}{c}{ Dilution $(w / v)^{\prime \prime}$} \\
& 1.10 & $1: 50$ & $1: 100$ & $1: 200$ & $1: 400$ \\
\hline Sample & & & & & \\
\hline Infected leaves & $0.43^{h}$ & 0.44 & 0.38 & 0.40 & 0.44 \\
Healthy leaves & 0.28 & 0.17 & 0.16 & 0.15 & 0.14 \\
Infected stems & 0.62 & 0.58 & 0.56 & 0.65 & 0.75 \\
Healthy stems & 0.24 & 0.18 & 0.17 & 0.16 & 0.15 \\
Infected pegs & 0.68 & 0.61 & 0.58 & 0.62 & 0.63 \\
Healthy pegs & 0.44 & 0.16 & 0.15 & 0.16 & 0.14 \\
Buffer & & & 0.14 & & \\
\hline
\end{tabular}

- Dilution based on the original weight of the tissue.

${ }^{b}$ Average of ELISA absorbance values at $410 \mathrm{~nm}$ of two replications in each of two experiments. Five ..... nan (momhinads and their leaves (combined) 
Table 2. Effect of mixing infected stem tissuc with healthy stem tissue for the detection of the peanut witches' broom mycoplasma-like organism by enzymelinked immunosorbent assay (ELISA)

\begin{tabular}{llll}
\hline $\begin{array}{l}\text { Proportion of } \\
\text { infected and } \\
\text { healthy stem tissues }\end{array}$ & \multicolumn{3}{c}{ Dilution of extract $(w / v)^{\mathrm{h}}$} \\
\cline { 2 - 4 } $1: 0$ (infected control) & $1.83^{\mathrm{c}}$ & 1.98 & 0.68 \\
$1: 1$ & 1.54 & 1.86 & 0.59 \\
$1: 4$ & 0.94 & 1.09 & 0.29 \\
$1: 9$ & 0.52 & 0.60 & 0.31 \\
$0: 1$ (healthy control) & 0.30 & 0.27 & 0.30 \\
Buffer & & 0.28 & \\
\hline
\end{tabular}

"Weighed portions of infected and healthy stems were mixed in the proportions given; 12 infected tissue was used for each individual analysis.

h Based on the original weight of the tissue. Five infected stems were combined as one sample in each experiment.

c ELISA values (at $410 \mathrm{~nm}$ ) represent means of four experiments with two replications each.

and stems from 24 individual shoots were tested to determine whether MLOs could be detected in all shoots with apparent witches' broom symptoms (Table 3). Using the mean of healthy samples plus two standard deviations as the upper negative limit (Clark, 1981), 20 of 24 stem samples were positive, and 16 of 24 leaflet samples from the same shoots were positive. Stems, therefore, appeared to be a better source for MLO detection. The four stem samples with absorbances similar to those of healthy controls (samples $1,6,8$ and 15) presumably had a very low MLO titre.

The PWB MLO antiserum was tested against 10 virus-infected and $M L O$-infected tissues using ELISA (Table 4). As expected, all virus-infected samples gave absorbances similar to those of buffer. Samples from MLO-infected plants, little leaf of brinjal, Datura sp. witches' broom and Vinca rosea witches' broom, also gave negative results.

The procedure developed by Clark et al. (1983) for partial purification of clover phyllody MLO was suitable for PWB MLO also. As in their experiments, absorbances due to plant constituents were a problem but were manageable. In the case of PWB MLO, three steps were necessary to minimize absorbances due to plant constituents: incubation of the resuspended first highspeed pellet with healthy peanut antiserum, a
Table 3. Enzyme-linked immunosorbent assay (ELJSA) absorbance values at $410 \mathrm{~nm}$ from individual samples of peanut shoots (leaves and stems) with witches' broom

\begin{tabular}{|c|c|c|c|c|c|}
\hline \multirow[b]{2}{*}{ Sample } & \multicolumn{2}{|c|}{ A $410^{4}$} & \multirow[b]{2}{*}{ Sample } & \multicolumn{2}{|c|}{ A $410^{a}$} \\
\hline & Leaves & Stems & & Leaves & Stems \\
\hline 1 & 0.21 & 0.21 & 13 & 0.70 & $2 \cdot 00$ \\
\hline 2 & 0.32 & 1.09 & 14 & 0.24 & 0.94 \\
\hline 3 & 0.34 & 0.86 & 15 & 0.26 & 0.44 \\
\hline 4 & 0.78 & 2.00 & 16 & 0.61 & 1.06 \\
\hline 5 & 0.92 & 0.76 & 17 & 0.52 & 1.43 \\
\hline 6 & $0 \cdot 19$ & 0.3 .3 & 18 & 0.44 & 1.46 \\
\hline 7 & 0.82 & 1.91 & 19 & 0.24 & 0.61 \\
\hline 8 & 0.21 & 0.21 & 20 & 0.70 & 1.64 \\
\hline 9 & 0.48 & 1.06 & 21 & $1 \cdot(1) 2$ & $2 \cdot 00$ \\
\hline 10 & 0.44 & 1.06 & 22 & 0.84 & 1.86 \\
\hline 11 & 0.73 & 1.84 & 23 & 0.86 & $2 \cdot 00$ \\
\hline 12 & 0.96 & 2.00 & 24 & 0.82 & 1.93 \\
\hline $\begin{array}{l}\text { Healthy } \\
\text { (mean) }\end{array}$ & $0.21^{h}$ & $\left(0 \cdot 22^{h}\right.$ & $\begin{array}{l}\text { Healthy } \\
\text { (mean) }\end{array}$ & $0 \cdot 24^{\prime}$ & $0 \cdot 3)^{c}$ \\
\hline
\end{tabular}

"Average of two replications. All samples were diluted to $1: 100(w / v)$. Absorbances above 2.0 were recorded as $2 \cdot 0$. All the values were greater than the mean of healthy controls plus two standard deviations except for leaf extracts of sample numbers $1,2,3,6,8,14,15$ and 19 , and stem extracts of samples $1,6,8$ and 15 .

'Leaf and stem healthy control means from the same ELISA plate on which infected samples 1-12 were tested.

c Leaf and stem healthy control means from the same ELISA plate on which infected samples 13.24 were tested.

single cross absorption of PWB MLO antiserum with healthy peanut extract, and pre-incubation of the antiserum in 1:10 healthy peanut extract for $45 \mathrm{~min}$ at $35^{\circ} \mathrm{C}$ during processing by ELISA. As a result of these steps, absorbance from healthy plant extracts at a 1:50 sample dilution and higher were close to those of buffer.

Although the ELISA procedure involved use of antiserum and anti-rabbit Fc conjugate at relatively low dilutions, both antiserum and conjugate can be collected, refrigerated and used again in several subsequent tests. Utility of the ELISA procedure for the detection of MLO in stem tissues of individual field-collected PWB samples was tested. Extracts from 24 of 27 samples gave absorbance values ranging from 0.48 to 0.69 when stems collected from apparently healthy adjacent plants gave 0.19 to 0.28 absorbance values. Three plants which gave negative results were collected in the month of June from sum- 
Table 4. Enzyme-linked immunosorbent assay (ELISA) absorbance at $410 \mathrm{~nm}$ for various infected tissues using peanut witches' broom antiserum

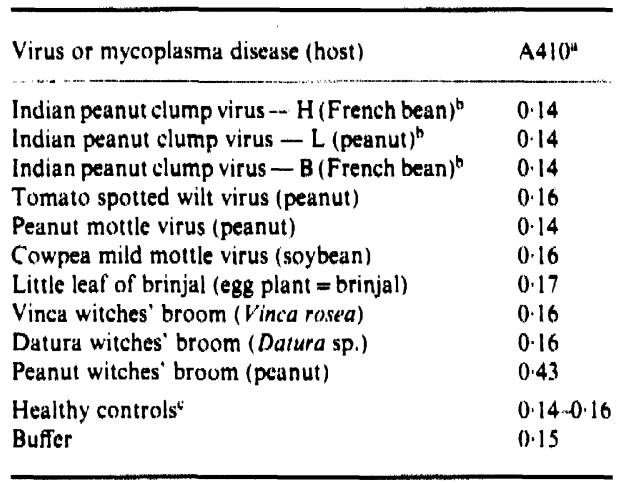

\footnotetext{
"Means of two replications in each of two experiments. Dilutions were $1: 100(w / v)$, based on original weight of the infected tissue.

${ }^{b} \mathrm{H}$, Hyderabad isolate: L. Ludhiana isolate; B. Bapatla isolate.

"Represent peanut, French bean, soybean, brinjal, Vinca rosea and Doturasp.
}

mer-grown peanut crops. Stems from these plants were grafted to healthy peanut plants and young leaflets from grafted plants showing WB symptoms were tested by ELISA. Extracts from all the three plants gave absorbance values three times those of healthy controls, indicating that field-collected source plants presumably had low MLO titre. Thus the antiserum produced could be used for MLO detection from the majority of field-collected samples. If MLO titre is low the test procedure reported in this paper cannot be applied for MLO detection. The greatest potential for detecting PWB MLO by ELISA would be in countries of eastern Asia for disease screening. However it is essential to determine whether the MLOs causing PWB in those countries are serologically related to the MLO causing PWB in India.

\section{REFERENCES}

Clark M.F. (1981) Immunosorbent assays in plant pathology. Annual Retiew of Phytopathology 19, 83106.

Clark M.F. \& Adams A.N. (1977) Characteristics of the microplate method of enzyme-linked immunosorbent assay for the detection of plant viruses. Journal of General Virology 34, 475-483.

Clark M.F., Barbara D.J. \& Davies D.L. (1983) Production and characteristics of antisera to Spiroplasma cilri and clover phyllody-associated antigens derived from plants. Annals of Applied Biology 103. 251- 259.

Edwards M.L. \& Cooper J.I. (1985) Plant vitus detection using a new form of indirect ELISA. Journal of Virological Methods 11, 309-.-319.

Lin C.P. \& Chen T.A. (1986) Comparison of monoclonal antibodies and polyclonal antibodies in detection of the aster yellows mycoplasmalike organism. Phytopathology 76, 45- 50.

Reddy D.V.R. (1984) Witches' broom. In: Compendium of Peanut Diseases (Ed. by Morris Porter, D. H. Smith \& R. Rodriguez-Kabana), p. 50. American Phytopathological Society, St Paul.

Sinha R.C. \& Benhamou N. (1983) Detection of mycoplasma like organism antigens from aster yellows-diseased plants by two serological procedures. Phytopathology 73, 1199-1202.

Sinha R.C. \& Chiykowski L.N. (1984) Purification and serological detection of mycoplasma-like organisms from plants affected by peach eastern $X$ disease. Canadian Journal of Plant Pathology 6, 200-205. 